HoST - Journal of History of Science and Technology

Vol. 13, no. 1, June 2019, pp. 28-50

10.2478/host-2019-0002

\title{
Influencing for Results: Bees, Beekeepers and Norwegian Pesticide Legislation
}

\author{
Anne Jorunn Frøyen \\ Jærmuseet \\ University of Agder, Norway \\ Anne.Jorunn.Froyen@jaermuseet.no
}

\begin{abstract}
Many who are worried about the disappearance of pollinating insects, question the role of pesticides and point to the need for stricter legislation regulating the use of these chemicals. This article studies the years between 1933 and 1953, when legislation regulating the use of pesticides against insects and weeds was established in Norway. It analyses how knowledge about effects of pesticides circulated from Norwegian honeybees, to their beekeepers and their network. It suggests that the actors' position and standing influenced what knowledge they put into circulation and what knowledge they suppressed. A knowledge hierarchy meant that some actors were powerful enough to influence the discourse on toxicity, established in those years.
\end{abstract}

Keywords: pesticides, arsenic, circulation of knowledge, honeybees, Norway 
Farmers use pesticides to eliminate species posing a threat to crops. The honeybees were amongst the first to warn of the fatal and often unexpected consequences of these substances. They visit flowers to collect nectar and pollen. If pesticides are used to kill insects, fungi or plants, there is a risk that they will also affect the honeybees. Bees can be poisoned when out of the hive, or there can be pesticides present in the nectar or pollen that they take back to the hive to feed the bee-larvae. As a result, whole colonies get weaker or even die out, and some beekeepers suffer part or total destruction of their production due to the practices of farmers who consider pesticides to be useful and necessary. The conflict of interests between these and other actors makes this an interesting case when studying how perceptions of toxicity are formed.

This is a study of how Norwegian beekeepers, and other stakeholders in the beekeeping community in Norway, met this conflict of interests between 1933 and 1953. During these years the conflict compelled a need for rules and regulations, which in turn set the premises for attitudes towards pesticides in years to follow. By tracing the knowledge that was produced and disseminated about the relationship between pesticides and honeybees, this survey attempts to reveal how perceptions of toxicity are formed, and which actors held the power in the discourse of toxicity.

Discourses about toxicity are controversial, and the debate concerning the interaction between pesticides and bees is also far from over. The recent success of the novel "The History of Bees" by Maja Lunde reflects how the possible negative effect of the interaction between man, honeybees and pesticides is a cause for concern, on a broad scale. The theme of her novel is Colony Collapse Disorder (CCD), the phenomenon where beekeepers loose between 30 and 90 percent of the colony. It was first discovered in the United States in 2006, ${ }^{1}$ and is now also well-known in Western Europe. ${ }^{2}$ There is disagreement about the causes of the phenomenon, but some believe that CCD is caused by small concentrations of insecticides called Neonicotinoids. Sainath Suryanarayanan and Daniel Lee Kleinman studied the beekeeping community in the United States following the discovery of CCD and concluded that the positions taken by the different actors, regarding the causes of the phenomenon, are in fact historical and are formed by structural factors, which have given certain communities

\footnotetext{
${ }^{1}$ Only the queen and a few nurse bees remain to care for the brood. The hive collapses, even though there is plenty of food, both honey and pollen, in the hive. Jamie Ellis, "Colony Collapse Disorder (CCD) in Honey Bees," Department of Entomology and Nematology, University of Florida/IFAS Extension, Publication no. ENY-150 1-4, revised version, [2007], 2016, https://edis.ifas.ufl.edu/ pdffiles/IN/IN72000.pdf (accessed April 30, 2019).

${ }^{2}$ https://www.efsa.europa.eu/en/topics/topic/bee-health (accessed April 16, 2019).
} 
epistemic dominance over other communities. ${ }^{3}$ There is a relationship between the knowledge of the actor, a historically established status of this knowledge, and the methods and standards the actor uses and refers to. ${ }^{4}$ The relative power of the actor will determine the extent to which she can influence both understanding of the problem, implementation of measures to prevent it, and laws and regulations. ${ }^{5}$ José Ramón Bertomeu confirms this in this issue studying expert communities and their connection to economic and political power.

\section{Mid-twentieth century beekeeping in Norway}

Due to the rather cold Norwegian climate honeybees are mainly kept in the southern part of the country. At the start of the 1930s there were approximately 3000 beekeepers and 21000 beehives, kept in gardens as a hobby, and on both smaller and larger farms where sale of honey gave an extra income. ${ }^{6}$ Hardly any beekeepers made a living solely from honey production. ${ }^{7}$

Honeybees are like wild bees, bumble bees and butterflies, important pollinators, benefiting fruit growers. Good conditions for producing fruit in Norway are found along the fjords on the west-coast, where there were hardly any beehives, ${ }^{8}$ and in the area around Oslo and Oslofjord in the south-east, where most of the honeybees were kept. Since most of the pesticides in the country were used by fruit farmers during the $1930 \mathrm{~s}^{9}{ }^{9}$ it was the region in the south east that

\footnotetext{
3 Sainath Suryanarayanan and Daniel Lee Kleinman, "Be(e)coming experts: The controversy over insecticides in the honey bee colony collapse disorder," Social Studies of Science 43, no. 2 (2012): 215-40, on 216.

${ }^{4}$ Suryanarayanan and Kleinman, "Be(e)coming experts," 219; Daniel Lee Kleinman and Sainath Suryanarayanan, "Dying Bees and the Social Production of Ignorance," Science, Technology \& Human Values 38, no. 4 (2012): 492-517.

5 Suryanarayanan and Kleinman, "Be(e)coming experts," 219; Emmanuel Henry, Ignorance scientifique et inaction publique. Les politiques de santé au travail (Paris: Presses de Sciences Po, 2017).

${ }^{6}$ In 1929 nearly 80 percent of the beehives were situated in the counties near Oslo and along the fiord south of the city and in the counties of Telemark and Aust-Agder further south and west along the coast. Central bureau of statistics, Norges offisielle statistikk VIII, no. 134 (1930), 2-3. There were beehives on 1.7 percent of properties in the country in 1929. Central bureau of statistics, Norges offisielle statistikk VII, no. 188 (1932), 344.25 percent of the beehives were kept on properties smaller than five acres. 25 percent of the properties were from 20 to 50 acres, keeping 19.5 percent of the beehives. 22 percent of the farms were larger than 50 acres, keeping 35 percent of the beehives. Central bureau of statistics, Norges offisielle statistikk VIII, no. 134 (1930), 4-5.

7 Alfred Skår, "Birøkterens plass som smånæring," Birøkteren (April 1939), 54-55; T.J. Bakken, "Birøkt i Danmark og Norge," Birøkteren (April 1963), 62-65.

${ }^{8}$ In Norway they grew apples, pears, plums and cherries. Along the fjords they harvested in 192917.5 percent of the apples, 36.4 percent of the pears, 14.3 percent of the plums and 14.4 percent of the cherries. Central bureau of statistics, Norges offisielle statistikk VIII, no. 145 (1931), Table 2, 90.

${ }^{9}$ Central bureau of statistics, Norges offisielle statistikk X, no. 40 (1942), 122.
} 
saw most interaction between pesticides and honeybees, and here that the problems following this interaction got more attention during the 1930s and 40s. ${ }^{10}$

After World War II, beekeeping gradually moved away from the highly productive agricultural area around Oslo, towards the south and west. It seems like there were two main causes for this; the first came as an effect of modernization of agriculture. Beekeepers were pushed away by farmers that cultivated more of their land into larger cornfields. The old meadows with a mixture of plants were harvested earlier in the summer, before the pollen and nectar became available for insects, and an increased use of fertilizer gradually changed the flora in favour of plants that did not attract bees. ${ }^{11}$ Pesticides removed weeds that also were valuable plants for the bees. As a result, such intensive agricultural areas became expanding deserts to honeybees. ${ }^{12}$ Secondly, beekeepers were pulled to the large remote areas of moorland heather in the south and west, where honeybees could find valuable food during late summertime. This became an opportunity from late 1930s when beekeepers gained the necessary knowledge to move the beehives successfully during season. ${ }^{13}$

\section{Sources, representation and method}

The majority of Norwegian beekeepers were members of The Norwegian Beekeepers Society, and the main source in this study is articles in their monthly magazine Birøkteren (The Beekeeper). ${ }^{14}$ This magazine, published once a month, provided knowledge and information about honeybees and beekeeping, through articles written by experienced beekeepers, Norwegian experts, and researchers in the field. It published, in addition, articles from foreign

\footnotetext{
${ }^{10}$ In the south-east they kept 80 percent of the honeybees (see note 6 , above) and harvested 51 percent of the apples, 42 percent of the pears, 50 percent of the plums and 45 percent of the cherries. Central bureau of statistics, Norges offisielle statistikk VIII, no. 145 (1931), Table 2, 90.

${ }^{11}$ Oddvar Olsen, "Velkommen til Sørlandet," Birøkteren (July 1956), 113-15; Odd Rosenberg, "Bot og erstatning," Birøkteren (April 1959), 57; L. Sandrud, "Litt praksis i bigården,” Birøkteren (April 1959), 63-64.

12 Sandrud, "Litt praksis i bigården," 63-64.

13 “Radikal omlegning av birøkten i Asker og Bærum," Birøkteren (February 1966), 38-39.

${ }^{14}$ In 193995 percent of the beehives in Norway were owned by members of The Norwegian Beekeepers Society. During the 1930s beekeeping expanded in Norway and the number of hives doubled, while the numbers of members in their society decreased from 1935 until 1939, and in 1939 only 56 percent of the hives were owned by members of their society. During World War II beekeepers had to be a member of the Norwegian Beekeepers Society to get sugar needed for feeding their bees during the winter, as a consequence about 100 percent of the beekeepers became members. This lasted until rationing stopped in 1952. T.J. Bakken and Odd Rosenberg, Slipp biene til. Norges Birøkterlag 75 ar 1884- 1959 (Porsgrunn: Brødrene Dyrings boktrykkeri, 1959), 266-67; Birøkteren (August 1960), 150. Central bureau of statistics, Norges offisielle statistikk VIII, no. 134 (1930), Table 3, 120-21; Central bureau of statistics, Norges offisielle statistikk IX, no. 191 (1940), Table 5, 140-41; Central bureau of statistics, Norges ofisielle statistikk XI, no. 40 (1950), Table 6, 186-87; Central bureau of statistics, Norges offisielle statistikk XII, no 40 (1961), Table 6, 202-203.
} 
publications, other Norwegian specialist periodicals and from conferences. It also included questions, opinions and knowledge from beekeepers and related professionals, the magazine's editorial staff and leaders of the association, along with answers from professionals working in related fields and academic experts. In this way The Beekeeper played an important role in the network of actors who were interested in beekeeping, the production of honey or other beerelated businesses.

Knowledge that is circulated in such networks has a potential to induce change, and can itself be changed and reformed. The actors in the network are not passive receivers of knowledge, quite the opposite. Knowledge provides the possibility for power and influence for all actors in the network. ${ }^{15}$ Seen in this perspective knowledge is dynamic and it opens up for a diversity of actors. ${ }^{16}$ By looking for actors that initiate, hinder or maintain the circulation of knowledge, and how they exercise influence over the flow of knowledge, we can ascertain different forms of the exercise of power. ${ }^{17}$ Here the circulation of knowledge about bees and pesticides in the magazine The Beekeeper is the basis for an analysis of how actors contributed to the forming of Norwegian regulation and their influence on the discourse of toxicity. ${ }^{18}$ In this case the magazine mainly acted as a carrier of knowledge, though on some occasions the editors of The Beekeeper acted by either promoting or hindering knowledge circulation. ${ }^{19}$

The beekeepers had different backgrounds; from ordinary farmers and garden owners, to highly educated academics and wealthy members of the upper-classes. It was likely easier for those in the latter groups to express their opinions and attitudes in The Beekeeper. To restrict an analysis of the circulation of knowledge to this source alone may mean that those who were active in The Beekeeper are credited with a greater influence and power than they had in reality, and that other actors are hidden. One may also ask if the editors of The Beekeeper acted by not publishing some articles or letters and promoting others, thereby influencing what knowledge was circulated. This is hard to prove; there is however no indication that the editors of The

${ }^{15}$ Johan Östling and David Larsson Heidenblad, "Cirkulation - ett kunskapshistoriskt nyckelbegrepp," Historisk Tidskrift 137, no. 2 (2017): 269-84, on 274. When using the term "Circulation," Östling and Heidenblad refer to Zentrum Geschichte des Wissens in Zürich.

${ }^{16}$ Ibid., 279.

17 Ibid., 283; Kostas Gavroglu, et al., "Science and Technology in the European Periphery: Some Historiographical Reflections," History of Science 46, no. 152 (2008): 153-75; James Secord, "Knowledge in Transit," Isis 95, no. 4 (2004): 654-72.

${ }^{18}$ This study is also inspired by David Larsson Heidenblad, "Mapping a New History of the Ecological Turn: The Circulation of Environmental Knowledge in Sweden 1967," Environment and History 24, no. 2 (2018): 265-84.

${ }^{19}$ Heidenblad, "Mapping a New History of the Ecological turn," 2, cites the Swiss historians Philipp Sarasin and Andreas Kilcher who see knowledge as an "intrinsically communicative phenomenon" that "requires a medium or a carrier." For science as communicative practice see Secord, "Knowledge in Transit." 
Beekeeper hindered any actors publishing their views in the magazine during the years from $1933-1953 .{ }^{20}$

I believe that The Beekeeper is a good source for this analysis, because a variety of actors were active in the magazine, including ordinary beekeepers, and the magazine published articles on a wide variety of topics. Furthermore, this study is an analysis of how power was exercised by initiating, preventing or maintaining the circulation of knowledge. The main aim of The Beekeeper was to disseminate knowledge. The magazine reached a large number of beekeepers and actors who sought power and could use it to affect circulation of knowledge in The Beekeeper. Thus, publication in The Beekeeper also indicated power. ${ }^{21}$

At the end of the nineteenth century, Norwegian agriculture, along with agriculture in the rest of Western Europe, began to test and implement the use of the pesticides. At the time when the use of pesticides became an issue between beekeepers and fruit growers, poisons to kill animals had been used routinely in Norway for nearly 100 years. Historians May-Brith Ohman Nielsen and Anne Mette Seines indicate that the poisons were socially and culturally accepted, and this probably also affected attitudes towards other poisons in Norwegian society. There was a general idea that poisons would only affect the species they were meant to attack. ${ }^{22}$ Also beekeepers themselves experimented with poisons, and used them to try to get rid of honeycomb moths, mites or mice and rats that could eat the honey in the hive. ${ }^{23}$ Knowledge of how to use the poisons and how they affected their livestock circulated in The Beekeeper, and as elsewhere in society, beekeepers probably also understood poisons as remedies that targeted some species, and left others unharmed.

The first warning that pesticides posed a threat to bees was published in The Beekeeper as early as $1904 .{ }^{24}$ When this study starts, thirty years later, the conflict of interests between beekeepers

\footnotetext{
${ }^{20}$ Studying the archive from The Beekeeper might give an answer to this, but this archive is at present not available.

${ }^{21}$ Central archives from the The Norwegian Beekeepers Society would have complemented this study. These archives are not available. Three archives from local departments of this society were investigated, the material reinforced the findings in The Beekeeper (Archives from Rogaland Beekeeping Society, Jæren Beekeeping Society and Sandnes Region Beekeeping Society).

${ }^{22}$ May-Brith Ohman Nielsen and Anne Mette Seines, "Poison to the Beasts: Changing Poisons and Poisoning Practices in Campaigns to Kill Norwegian Birds and Mammals, 1845-1967," Environment and History (2018) Fast Track, https:/www.ingentaconnect.com/content/whp/eh/pre-prints/contentwhp_eh_1333.

23 A.G. Harrison, "Kontroll med voksmøll i lagrede tavler," Birøkteren (March 1939), 43-45.

${ }^{24}$ Rolf Lunder, "Kampen mot bisjukdommene," in Slipp biene til. Norges Birøkterlag 75 ar 1884- 1959, eds. T.J. Bakken and Odd Rosenberg, 192-98 (Porsgrunn: Brødrene Dyrings boktrykkeri, 1959), 197. About the understanding of honeybees as valuable pollinators in fruit production in late nineteenth century see James Whorton, Before silent spring: pesticides and public health pre-DDT America (Princeton, NJ: Princeton University Press, 1974), 27-28.
} 
and other actors in the field of agriculture became a theme in the magazine. It concerned the honeybees' reaction to the practices of fruit farmers and there was disagreement amongst the actors as to whether the bees were harmed by the toxins or not. ${ }^{25}$ The substances usually used by fruit farmers in Norway were lime sulphur against fungus, mites and scale insects; Bordeaux mixture, with copper sulphate as the active ingredient, against fungus; nicotine sulphate against aphids; and arsenic compounds, mainly lead arsenate, against chewing insects. These chemicals were often mixed together before being sprayed on the fruit trees. ${ }^{26}$

\section{"Is spraying of fruit trees dangerous for bees?"}

An issue is a topic that causes debate, which gathers supporters and detractors, and that becomes politicized. A non-issue is not debated, because there is general agreement around it, or because the issue affects a few, in closed groups. ${ }^{27}$ The Beekeeper started a circulation of knowledge and made the bees' reactions to pesticides an issue in June 1933, by asking its readers: "Is spraying of fruit trees dangerous for bees?"28

The backdrop was an article The Beekeeper received from one of its readers regarding the use of the insecticide lead arsenate. In the article there was a question asking whether beekeepers should avoid spraying lead arsenate on their fruit trees, to be sure not to harm their honeybees and an answer, given by a representative from the company selling the insecticide. By reprinting the article and encouraging their readers to pass on their own experience of honeybees reaction to pesticides, The Beekeeper probably reflected a concern amongst their readers about how these chemicals affected the honeybees, and that the use of pesticides was common in orchards in Norway in $1933 .{ }^{29}$ Therefore the question "Is spraying of fruit trees dangerous for bees?" needed to be answered.

${ }^{25}$ Lunder, "Kampen mot bisjukdommene," 198.

${ }^{26}$ Rolf Lunder, Undersøkelser vedrørende forgiftning av bier som folge av frukttresprøiting (Oslo: Grøndahl \& søns boktrykkeri, 1939), K5.

${ }^{27}$ Kristin Asdal, "What is the issue? The transformation capacity of documents," Distinktion: Journal of Social Theory 16, no. 1 (2015): 74-90.

28 "Er frukttresprøitningen farlig for biene?" Birøkteren (June 1933), 121-23.

${ }^{29}$ Statistics of Norway surveyed Norwegian agriculture every tenth year starting in 1917. Farmers were asked about their use of pesticides for the first time in 1938/1939. Since it was only in a few remote municipalities that farmers did not use pesticides, I assume that they were extensively used also in the beginning of the 1930s. Central bureau of statistics, Norges offsielle statistikk X, no. 9. (1942), Table 5, $116-31$. 
Four main groups of actors in the years following circulated knowledge about the connection between poisoning of bees and pesticides. ${ }^{30}$ These were representatives from companies distributing pesticide in Norway (pesticide distributors), beekeepers, the specialist interest group "The Norwegian Beekeeping Society" together with their magazine The Beekeeper, and lastly, what I call "experts of knowledge," specialists not because of their knowledge of honeybees, but by virtue of their profession. These actors played a part in defining the perceived toxicity of pesticides and shaping the regulations concerning the handling of these chemicals, passed by Norwegian parliament in 1941. It then became illegal to treat plants with chemicals containing arsenate as long as the plants were in flower. ${ }^{31}$ Following is a review of the knowledge these actors put into circulation within the network, which thereby contributed to establishing one type of knowledge, whilst hindering another.

\section{Actors enter the scene, 1933 - 1934}

The answer given by the pesticide distributor who sold the arsenate-containing pesticide was double-sided, and gave no conclusive answer to the question of whether lead arsenate would poison bees, or could safely be used. He advised against spraying lead arsenate during flowering as a preventative measure against such poisoning, despite the fact that neither Norwegian research institutions nor fruit farmers had reported any cases of poisoning, from this or other pesticides. He had also not seen any indications of this in international literature. By examining orchards in spring, he had also observed that insects could attack and destroy what could become a rich fruit harvest:

It turns out that this year there is a terrible amount of insect eggs in the trees... After a recent survey of the best orchards in the area, we found up to 50 eggs on each small fruit branch, mostly of the apple sucker, but also of other insects.

About 3 weeks ago I took some of the branches and put them in water. Now in the last few days the apple suckers have hatched and have begun to creep in between the half-open petals of the flower-buds...

It's important to spray before the newly-hatched insects have time to chew too far in to the half-open buds.

At the same time, it is also important to protect the young leaves from scab fungus. ${ }^{32}$

\footnotetext{
${ }^{30}$ Here I read the issues of The Beekeeper in the years from 1933 to 1954 . Articles where the noun pesticide was used or the act of using the chemicals was described, were singled out. The author or the actor sending the article to The Beekeeper was identified, and the knowledge they conveyed analyzed, to see if they presented new knowledge, maintained knowledge other actors had introduced, argued against that knowledge or ignored it.

31 "Lov," Birøkteren (April 1942), 57.

32 "Er frukttresprøitningen farlig for biene?” Birøkteren (June 1933), 122-23. My translations.
} 
Although he recognized honeybees as useful insects in orchards due to their pollination, his knowledge was centred on identifying insects that could have a harmful effect on fruit production or fruit quality, and how to prevent these harmful effects by eradicating those insects using pesticides.

The author of the article came across as trustworthy, as did the advice and knowledge he conveyed in the article: To eradicate harmful insects the farmer should carefully follow a fungicide and insecticide spraying schedule. Since lead arsenate could harm bees, it should only be used on apple trees before and after flowering. According to the author, nicotine sulphate was harmless and this pesticide should be used when the tree was in flower. In this way they could avoid poisoning the honeybees whilst killing the harmful insects. Thus, he introduces the idea that some pesticides are toxic, others are not, and some insects are good, the honeybees, while others are bad, like the apple sucker. Insects that did no harm or were beneficial like bumblebees, wild-bees or butterflies, are not mentioned.

Lead and arsenate are poisons with both acute and chronic effects on humans and the environment. ${ }^{33}$ When using lead arsenate to kill harmful insects in orchards it is very likely that there will be residues of the chemical on the fruit and the soil under the trees will be contaminated. In the United States lead arsenate was commonly used in apple orchards because of its effects against the codling moth, and in the beginning of the twentieth century, knowledge about the harmful effects of residues on fruit were circulating in the media. ${ }^{34}$ In 1919 researchers concluded that "common washing practices did not adequately remove arsenic residues from produce," and there was a discussion around how many apples a person could safely eat daily. ${ }^{35}$ In the 1930s concerns about pesticide residues increased and in 1933 the federal government passed a law limiting allowable residues of lead on fruit in the United States. ${ }^{36}$ Britain had even stricter regulations. ${ }^{37}$ Probably these harmful effects were known to experts within agriculture in Norway. They were not, however, an issue in this article. ${ }^{38}$

${ }^{33}$ C.H. Walker, R.M. Sibly, S.P. Hopkin, and D.B. Peakall, Principle of Ecotoxicology (Boca Raton, FL: CRC Press, 2012), 5. See also the paper by Bertomeu-Sánchez in this issue.

${ }^{34}$ Frederick Rowe Davis, Banned: A History of Pesticides and the Science of Toxicology (New Haven \& London: Yale University Press, 2014), 2-3.

${ }^{35}$ Therese Schooley, Michael Weaver, Donald Mullins, and Matthew Eick, "The History of Lead Arsenate Use in Apple Production: Comparison of its Impact in Virginia with Other States," Journal of Pesticide Safety Education 10 (2008): 22-53, on 32. These authors refer to Harold H. Shepard, The chemistry and toxicology of insecticides (Minneapolis, Minn: Burgess Publishing Co, 1939).

${ }^{36}$ See Whorton, Before silent spring, about the dispute over the harming effects from residues on fruit in the United States.

${ }^{37}$ Schooley, Weaver, Mullins, and Eick, "The History of Lead Arsenate," 32; Davis, Banned, 11.

${ }^{38}$ Norwegian experts within plant protection cooperated with peers abroad. Jac Fjelddalen, "Nordisk og internasjonalt samarbeid," in Kampen mot planteskadegjorerne, eds. Hans Kr. Brenna, Arnstein Bruaset, and Kåre Årsvoll, 165-167 (Ås: Norwegian Agricultural Advisory Centre, 1991). 
The pesticide distributor's knowledge extended only to the pesticides' ability to target certain insects. According to his knowledge, it was possible to single out one part of nature; the harmful insects, and eradicate them with poison and, if the right method was used, the nature surrounding these insects would be unaffected.

To get good honey yields, beekeepers must have knowledge gained through experience; they need to know how their bees interact with each other and with their surroundings. Still, in their magazine, the beekeepers expressed differing views on how pesticides affected the honeybees. Those who both produced fruit and kept bees, considered the pesticides as potentially harmful, but that with the correct practice, the fruit trees could be sprayed without poisoning the bees. Two such beekeepers were the first to share their experiences in The Beekeeper in 1933. Both had sprayed fruit trees with pesticides for many years, one of them for 20 years, without observing any effect on the bees. They took the bees into consideration when spraying, but had also observed that the bees could take care of themselves, by going into the hive, or keeping away from the spraying when they were out flying. ${ }^{39}$ These beekeepers shared the knowledge given by the pesticide distributor; pesticides were a necessary tool to fruit-producers and harmless when used in the right way.

When beekeeper Wulff-Nielsen responded to this half a year later, he started circulating different knowledge, and exhibited the diverging positions amongst the beekeepers. With reference to international specialist literature he concluded that spraying lead arsenate, lime sulphur and nicotine sulphate, all the usual pesticides, both killed and weakened bee colonies. Where the adviser from the pesticide distributor had pointed to his observations of the harmful insects as documentation for the necessity of using pesticides, Wulff-Nielsen described his own observations of the consequences of the same pesticides used by fruit-producers in his neighbourhood:

The poisoned bees that do not die on their way home, come creeping out over the landing board and lie in groups on the ground, some very swollen, the poisoned larvae are nearly white, dried out and without the rotting smell that is characteristic with bee sickness. ${ }^{40}$

Wulff-Nielsen argued that there was sufficient knowledge of the negative effects of pesticides on bees and he was critical of the distributor chain that "agitated powerfully" for them and to the county gardeners and the State Entomologist who allowed spraying even when the trees were in flower. Why did they set up spraying schedules that poisoned the bees, when Danish research showed that there were other alternatives? Pesticides also harmed fruit-farming since these chemicals killed the honeybees that pollinated the fruit:

39 "Er frukttresprøitningen farlig for bierne?" Birøkteren (June 1933), 144-45.

${ }^{40}$ Wulff-Nielsen, "Er frukttresprøitningen farlig for bierne?" Birøkteren (February 1934), 28-30. My translation. 


\begin{abstract}
This really raises the question whether it is "fair play" and morally defensible, that one group of fruit growers has the right to poison flowers and thereby kill the bees which they really should rather protect, as they are one of the most important factors for any fruit harvest. ${ }^{41}$
\end{abstract}

For this beekeeper, it was not possible to use pesticides without harming the bees. Following this article, The Beekeeper printed the legislation that had protected the honeybees by regulating the use of lead arsenate in the district of Stade near Hamburg in Germany since April 1931. Thus, The Beekeeper confirmed that arsenates were toxic, and silenced Wulff-Nielsen's knowledge about the other pesticides. ${ }^{42}$

P. Stang, who had both fruit trees and kept bees, answered Wulff-Nielsen. He was also critical of the Norwegian State Entomologist's passive approach to arsenate and asked for a clear ban of the use of this agent whilst trees were in flower, as they had done in Stade. He based his argument on international specialist literature and research papers and disagreed with WulffNielsen's view of pesticides as generally harmful. He concluded that pesticides containing arsenic were toxic, sulphur less toxic and that pesticides containing nicotine was hardly toxic at all, and was of the opinion that the bees kept themselves away from the agents containing nicotine. As such, they were not harmful to the bees at all. Stang suggested solving the problem by adding an ingredient to the lead arsenate that would scare the bees away from it. ${ }^{43}$

It seems that in 1933/1934 there was a shared understanding of arsenate as toxic to honeybees amongst the actors. Beekeepers disagreed however on whether it was possible to use the toxic chemicals in such a way that honeybees were spared from being harmed, and about the toxicity of the other pesticides. Their answer to the question of whether pesticides harmed honeybees reflected their position. The beekeepers that produced fruit wanted to use pesticides and knew how to take precautions when spraying so as not to harm their honeybees. To them, it was possible to control the effects of the chemicals. Whereas Wulff-Nielsen did not use pesticides himself and watched his bees suffering as a result of others spraying their trees to eradicate harmful insects. In his view pesticides harmed the bees. He also proposed that pesticides were a threat not only to honeybees, but to beneficial insects in general, and opposed the idea that poisons would not affect the rest of nature surrounding the harmful insects. ${ }^{44}$

The knowledge put forward by Wulff-Nielsen was hindered from further circulation by two articles in the next issue of The Beekeeper. In the first, the editor of Norsk Hagetidende (The Norwegian Gardeners' Times) used his position to discredit Wulff-Nielsen. He stated that it was

\footnotetext{
41 Ibid.

42 "Hvad der gjøres i utlandet for beskyttelse av bier under spøitning av frukttrær," Birøkteren (February 1934), 30-31. Translated and reprinted from Leipzinger Bienen Zeitung.

43 P. Stang, "Frukttresprøitning i åpen blomst og bier," Birøkteren (April 1934), 73-75.

${ }^{44}$ Wulff Nielsen, “Er frukttresprøitningen farlig for bierne?” Birøkteren (April 1934), 72-73.
} 
well-known to the authorities that bees and bumblebees were harmed when spraying arsenic pesticides on flowers when open. In some countries this also was forbidden by law; WulffNielsen hadn't read the article he referred to properly. The State Entomologist had tried out the means suggested, and they were found impossible to implement at some locations. ${ }^{45}$ This actor maintained the knowledge that pesticides were necessary tools when growing fruit, and by using proper methods when spraying it was possible to control the effect of the pesticides on honeybees and other beneficial insects.

The second article was written by Rolf Lunder, one of the "experts of knowledge" who ran state-funded research on bees and honey production from 1934 and onwards. Lunder was the first Nordic professor in beekeeping, and is famous for modernizing Norwegian beekeeping and honey-production. ${ }^{46}$ His knowledge base was both as a beekeeper and as a trained scientist. He reinforced the idea that pesticides varied. The idea that their effect on bees was controllable was maintained, and indeed strengthened due to the fact that several actors repeated and expanded on this shared understanding.

Lunder highlights the advantages of pesticides. In his opinion, the development and quality improvements in Norwegian fruit growing were "mainly due to spraying of fruit trees" and it was not possible to refrain from spraying either wholly or partly, as suggested by WulffNielsen. ${ }^{47} \mathrm{He}$ acknowledged that some of the fruit tree pesticides, especially those containing arsenate, could poison bees, and explained why spraying with arsenate before and after flowering did not lead to any harm. In this way Lunder reinforced the idea that the interaction between insect, pesticide and flower was controllable. When he asserted that the symptoms observed by Wulff-Nilsen could have other causes than poisoning, the level of detail regarding the bees and their sickness also made his knowledge appear trustworthy. When he put the case that knowledge concerning the effects of pesticides was uncertain, Lunder also demonstrated the need to undertake research to get a concrete answer to the question of whether spraying open flowers with arsenate was dangerous for bees.

\footnotetext{
45 "Er frukttresprøitningen farlig for bierne?” Birøkteren (May 1934), 113.

${ }^{46}$ Rolf Lunder, "Forsking og forsøk i birøkten," in Slipp biene til. Norges Birøkterlag 75 ar 1884- 1959, eds. T. J. Bakken and Odd Rosenberg, 187-91 (Porsgrunn: Brødrene Dyrings boktrykkeri, 1959); Jac Fjelddalen, "Skadedyrforskningen gjennom 100 år," in Kampen mot planteskadegjørerne Plantevernet i Norge 100 år 1891 - 1991, eds. Hans Kr. Brenna, Arnstein Bruaset, and Kåre Arsvoll, 137-47 (Ås: Norwegian Agricultural Advisory Centre, 1991); https://nbl.snl.no/Rolf_Lunder (accessed April 10, 2019).

${ }^{47}$ Rolf Lunder, “Er frukttresprøitningen farlig for biene?” Birøkteren (May 1934), 111-13.
} 
After two articles that expressed agreement with Lunder later that summer, the debate ended without a final answer to the question of whether pesticides were dangerous to bees. ${ }^{48}$ Several actors had taken part in the discussion. The idea that pesticides were toxic to species other than honeybees and the targeted insects was effectively silenced. So was the knowledge that there might be alternatives to pesticides for protecting the fruit harvest. The majority of the actors held the view that pesticides containing arsenic were toxic, whilst other pesticides were not toxic or that their harmful effects could be controlled. In practice the bees continued to be poisoned, such that the issue came up again in 1935.

\section{The pesticides need to be properly tested, $1935-1940$}

In august 1935 the board of the Norwegian Beekeepers Society received a letter from one of its regional departments describing how pesticides affected their bees and their honey production. This initiative resulted in the research project that gave the final answer to the question of whether pesticides were dangerous to bees. Different actors influenced both the question being asked and the methods used to answer it. These actors thereby influenced the knowledge and lack of knowledge that led to the shaping of the regulations implemented in 1941.

The letter came from beekeepers in a region to the south east, rich in both honey production and fruit farming. Here beekeepers observed that simultaneously with the flowering of blossom in spring 1935, the honeybees fell down to the ground, and lay there crawling around until they died. The result of this, was that, after a short time the hives were depopulated and died out. If the phenomenon continued they would be forced to stop their honey production, wrote these beekeepers to their board. ${ }^{49}$

The "layman's opinion" was that this was caused by the spraying of pesticides but the beekeepers were not so sure. ${ }^{50}$ The symptoms they observed were similar to those described by Wulff-Nielsen, but their doubts appears to be connected with the knowledge shared by the expert Rolf Lunder the year before, in The Beekeeper. This can also explain the way the local beekeepers' society went to work to try and find the cause. They put together a committee "to ensure that the issue was properly surveyed." The committee collected dead bees and sent them to Lunder for analysis. They made a survey of the condition in the hives by collecting statistics on production. All beekeepers took part and the conclusion was indisputable: in areas

\footnotetext{
${ }^{48}$ Mikjel H. Sørlie, "Er frukttresprøitningen farlig for biene," Birøkteren (June 1934), 126; "Biene og frukttrærnes sprøytning," Birøkteren (August 1934), 168. This translated and reprinted article gave insight into research in Erlangen, Netherlands.

${ }^{49}$ H.P. Langkaas, O.T. Innleggen, and Aslak Heldag, "Til styret for Norges Birøkterlag," Birøkteren (March 1936), 37-39.

${ }^{50}$ Ibid., 39.
} 
where pesticides were not used the average honey production was $8.3 \mathrm{~kg}$ honey per hive; where there was occasional spraying, $4.09 \mathrm{~kg}$; and where there was "normal" spraying, 1.25 $\mathrm{kg}$ honey per hive. The numbers of swarms pointed in the same direction. They added other facts that supported the conclusion. The first time the phenomenon was observed was when farmers started spraying fruit trees in the area, in 1933. The following year there was very little flowering of blossom, little spraying and the bees were healthy. However, in 1935 there was a standard use of pesticides on the fruit trees and the bee sickness came back. ${ }^{51}$

The local beekeeping society committee did not hold a definite opinion about pesticides, nor did they refer to international studies or national literature. They gathered local data in a systematic way and presented evidence that indicated that pesticides had damaging effects, and then described what the consequences of this would be for their business, delivering the case and the responsibility over to the board of The Beekeeping Society. They put their knowledge into circulation and asked for a solution. ${ }^{52}$

At a board meeting in the Norwegian Beekeepers Society in October 1935, the letter from the committee on the mass-death of bees was on the agenda: "It is of the utmost importance that a study is done to establish whether spraying of insecticides is harmful to bees." The board agreed and sent the issue further to those they regarded as having the knowledge to make the investigation: the "experts of knowledge." The board also agreed to publish all correspondence on the issue in The Beekeeper. ${ }^{53}$ In this way they maintained the circulation of knowledge about the possible damaging effects of the pesticides, but the board members did not form an opinion as to whether they were dangerous to bees or not.

The "experts of knowledge" were, beside Rolf Lunder, actors with different affiliations to honeybees and the beekeeping community. These were the State Entomologist, who should prevent and eradicate pests in agriculture, gardens and forests of Norway, and the State Horticulturalist who was responsible for national fruit, berry and vegetable production. One of their main tasks, and therefore also knowledge base, was how to prevent insects, weeds, fungi and other organisms from harming agricultural production. The Bee Sickness Committee had to prevent and map sickness among honeybees. The Norwegian Beekeepers Society appointed one member of the committee; the other members had their knowledge from other fields, like bacteriology or veterinary medicine. ${ }^{54}$

\footnotetext{
51 Ibid.

52 H. P. Langkås, "Massedød av bier i fruktresprøystingas fotefar," Birøkteren (March 1936), 40-41.

53 "Referat fra styremøte den 11 oktober 1935," Birøkteren (January 1936), 2; "Referat fra styremøte 17/1 1936," Birøkteren (March 1936), 33.

${ }^{54}$ C. S. Aaser, "Bipestens bekjempelse i Norge,” Birøkteren (January 1937), 9-15.
} 
The first expert that replied to the request from the Norwegian Beekeepers Society was the State Entomologist. His opinion was that the local beekeepers' committee had not used proper methods in examining the issue and that it was therefore impossible to draw any conclusions from the data they had collected. They should have sent approximately 100 samples of the dead bees to a university for chemical analysis. In addition, they should have collected data on the time of spraying and the pesticides that were used, in order to ascertain if there had been "any careless spraying." Then it would be possible to "take steps to have the rational spraying rules tightened up, or to introduce a ban on spraying with arsenate or copper pesticides during flowering of fruit trees blossom." 55 Thus the State Entomologist ignored the knowledge gathered by the local committee of beekeepers. So did the State Horticulturalist, who conferred with the State Entomologist and concluded: "It is about time that we gather(ed) enough good information about the relationship between the spraying of fruit trees and the death of the bees so that we can work safely both with fruit production and with the keeping of bees." ${ }^{56} \mathrm{He}$ asked the County Horticulturalist in the affected county to give the matter his full attention, and instructed him how to conduct his research. This was the start of a research project that ran for four years.

These two experts assumed that the bees did not die due to the pesticides, but due to the fruit farmers using wrong spraying methods. They supported the idea that there was a right way to spray, which would make it possible to successfully keep bees and still spray fruit trees with pesticides. ${ }^{57}$

The Bee Sickness Committee, the body concerned with infectious sickness in bees, had the item on its agenda in a meeting in December 1935. Lunder was at the meeting and he had studied the issue together with the local inspector from the Bee Sickness Committee. He described how the "mass-death" appeared:

The hive is severely weakened, and there are masses of dead and half-dead bees outside the hive. The sick bees lose the ability to fly and crawl around on the ground. Some of the bees had cramps and some are swollen up on the back of their body. Most of the sick bees were young bees. ${ }^{58}$

Ignoring that fact that Wulff-Nielsen had made the same observations in 1933, the Bee Sickness Committee asked Lunder, who was in receipt of a scholarship, to make a proposal for a plan to

\footnotetext{
55 Tor Hiorth Schøyen, “Norges Birøkterlag," Birøkteren (March 1936), 39.

56 S. Lysbakken, "Norges Birøkterlag," Birøkteren (March 1936), 39.

57 Guillen-Llobat also illustrates in his article in this issue how actors, by underlining that the method caused the accidents, were able to hide the poisoning effect of the chemical (cyanide).

58 "Utskrift av møteprotokollen for Bipestnevnden fra møte 11. desbr. 1935," Birøkteren (March 1936), $39-40$.
} 
"investigate the question of the dangers of spraying fruit trees with pesticides." Lunder started his investigations in the summer of $1936 .{ }^{59}$

Neither of the "experts of knowledge" trusted the results of the investigation performed by the local Beekeeping Committee, and thereby upheld the idea that knowledge gathered through experience was of a lesser value than knowledge produced by "scientific methods." This discounting of practical knowledge also occurred when a beekeeper shared his observations after large losses of beehives in the winter 1937/1938. Based on his own knowledge and experience he concluded that the pollen that was fed to the larvae was infected with pesticides that weakened the young bees for life. As a result, whole colonies died out. ${ }^{60}$

When Lunder answers this beekeeper, on behalf of the Bee Sickness Committee, he stated that it was not very credible that poisoning from fruit tree spraying could lead to such consequences, but he was not able to explain the irregularities that the beekeepers had observed. Lunder indicated, on behalf of the experts, that in order to solve the problem it had to be investigated by them, who knew about the issue, knew about bee sicknesses and knew how to use the correct methods in their examinations. ${ }^{61}$

When the research project ended, the results showed that this last beekeeper was right: contaminated pollen weakened the hives so that they did not survive the winter. The local committee of beekeepers was also right; it was pesticides that killed their bees. Whereas the State Entomologist was wrong; chemical analysis was not always a proper tool when detecting bee poisoning from pesticides. ${ }^{62}$

\section{Regulations were made, 1941}

In July 1939 Rolf Lunder summarised the results of the "investigations concerning possible poisoning of bees as a result of spraying of fruit trees" in The Beekeeper. The investigations had been conducted over four years and in two locations. In the affected district where the investigation started in 1935, there was observed "mass-death" amongst bees and larvae during flowering of fruit tree blossom. These were all in close proximity to sprayed trees.

In the second location, tests were done examining the effects of pesticides. It was concluded that the pesticides containing arsenate poisoned the bees, whereas the others (lime sulphur

\footnotetext{
59 Rolf Lunder, "Beretning fra forsøket med karbolsyre ved Småbrukslærerskolen,” Birøkteren (November 1936), 207-208.

${ }^{60}$ K. O. Thorsby, "Overvintring," (Over-wintering) Birøkteren (March 1938), 35-36.

${ }^{61}$ Rolf Lunder, "Overvintringen," Birøkteren (April 1938), 53-54.

62 State Entomologist Thor Hiorth Schøien argued that chemical analyses would tell if bees were poisoned by pesticides. Schøyen "Norges Birøkterlag," 39.
} 
and nicotine sulphate) were harmless.

A total ban on the use of arsenate-containing pesticides was unthinkable. These pesticides are completely necessary in the fight against certain damaging insects that appear after flowering. ${ }^{63}$

As a result, spraying had to be done in such a way that the bees could visit the fruit trees without being harmed. Thus, the honeybees were recognised as important in orchards, as useful tools to enhance fruit production, but they were not as important as the main product; the fruit. Beekeepers initiated the research through their letter to the board of the Norwegian Beekeepers Society, but the "experts of knowledge" planned and performed the research project. These actors set the premises, and thereby influenced both knowledge and ignorance produced by it.

The research was ended after five years in 1940. The Bee Sickness Committee then directed its attention towards the Department of Agriculture, with suggestions for the regulation of the use of pesticides on fruit trees, in accordance with the results of their research. ${ }^{64}$ On the 15 May 1941 it became forbidden in Norway to use arsenate pesticides on fruit trees during flowering. ${ }^{65}$

The idea that poisons could be controlled was already established when this study started in $1933 .{ }^{66}$ Following the circulation of knowledge about the interaction between insects and pesticides, the indication was that pesticides were regarded as efficient and necessary tools to eradicate insects harmful to fruit production and fruit quality. Several pesticides were used, and it was known that one of the active agents, arsenate, might also have negative effects on honeybees. Knowledge circulated about the effects and about how to control the poisoning agent. This knowledge formed the basis of the survey that started in 1936, and thereby influenced its conclusions. Whereas knowledge about the negative effects on other species was hindered from being circulated, so was the knowledge of the effects of other pesticides. The idea that pesticides were controllable agents was maintained and toxicity was considered as an effect working in the interaction between chemical and harmful insect. Other species that pesticides harmed were left out and the toxic effect on these taxa were not studied. The knowledge established about toxicity was taken further in the post-World War II period, when new synthetic pesticides appeared on the market.

63 "Litteratur," Birøkteren (July 1939), 137-41.

64 "Bipestnemdas årsmelding for 1939. Bisjukdommer," Birøkteren (August 1939), 159-61.

65 "Lov," Birøkteren (April 1942), 57.

${ }^{66}$ Nielsen and Seines, "Poison to the Beasts." 


\section{After 1945: new pesticides, old solutions}

Practical experience with the new synthetic pesticides in the war years was promising and DDT was seen as harmless to the species that it was not meant to affect, when this pesticide entered the Norwegian orchards in spring 1946. But already in September of the same year The Beekeeper initiated circulation of knowledge about the effect of this pesticide on bees, with the question: "Is DDT harmful to bees?" ${ }^{67}$ The question was put forward after a letter from two brothers who had suffered severe loss of beehives after their honeybees had collected pollen from flowers sprayed with DDT. The contaminated pollen had been carried into the hives. The brothers wrote to The Beekeeper after reading in The Norwegian Gardener's Times that DDT did not harm honeybees. Therefore, the issue was put forward by the same actors and in the same way as in 1933, where beekeepers sent a letter to The Beekeeper, which presented the issue to its readers and started circulation of knowledge about the interaction between honeybees and pesticides.

This first article about DDT in The Beekeeper illustrates how knowledge and perception of DDT altered according to the position of the actor. The pesticide producer, Geigy in Switzerland, was positive and was of the opinion that DDT was harmless. The Norwegian Gardener's Times was generally positive to pesticides, ${ }^{68}$ and held the opinion that the new substance was a "great step forward when it came to protecting the beekeepers' interests," and circulated knowledge about DDT as harmless:

When the spray has soaked in, one can see that the bees can walk over the leaves without being harmed. DDT works as is known as a nerve-agent, and the bees walk on their "toes" and have few nerves in their feet... The house-fly however touches what it walks on with the whole foot and it comes in good contact with its nerve-rich suckers with whatever it is walking on. This explains why bees can walk on an area sprayed with DDT, whilst a fly is quickly condemned to death. ${ }^{69}$

With their letter to The Beekeeper, the two beekeepers wanted to stop the knowledge spread by The Norwegian Gardener's Times. The Beekeeper gave the case to the Bee Sickness Committee. ${ }^{70}$ The Bee Sickness Committee claimed in their annual report that there had been several cases of "poisoning after fruit tree spraying" in 1946, with the DDT-containing substance Gesarol. The conclusion was that these substances were dangerous when they were sprayed on to

67 "Er DDT giftig for bier?" Birøkteren (September 1946), 136-37.

${ }^{68}$ May-Brith Ohman Nielsen, "Kverk Krekene! Strategier for å selje liv og død til norske hageeiere 1945-1975," in A selle liv og dod Kommersielle strategier og kulturuttrykk $i$ markedsforing av dod og dodsfrykt, ed. May-Brith Ohman Nielsen, 12-45 (Finland: UPEF University Press og Eastern Finland, 2014).

69 "Er DDT giftig for bier?," 136.

${ }^{70}$ Ibid., 136-37. 
open flowers. ${ }^{71}$ This knowledge was strengthened with reports from observations made by Bee Sickness Committees in two counties in May 1947..$^{72}$ Two months later, on the 4 July 1947 parliament asked the Ministry of Agriculture to form "laws on the prohibition of treating plants with chemicals that are harmful to bees." ${ }^{73}$ This applied to all substances containing arsenate, DDT, and two other synthetic pesticides; hexachloro6-6-6 and phosphor, used for "treating (spraying, dusting or similar) of fruit trees, berry bushes and other plants whose flowers are visited by bees." ${ }^{74}$ The distributors should make sure that the regulations were printed on the packaging. Breaking the law would be punished with fines. ${ }^{75}$

The new generation of pesticides were thereby included in the regulatory regime established in 1941. When the new hormonal agents against weeds were introduced in the spring of 1948, the problem became worse in the following years and the complaints multiplied as these herbicides were intensively used in agriculture, in gardens, on roadside verges, train-lines and other places where vegetation was defined as weeds. ${ }^{76}$ Both beekeepers and the "experts of knowledge" agreed that giving information to the users of the pesticides would solve the issue, ${ }^{77}$ but some beekeepers expressed discontent with the situation, and requested improvement of the rather inconsistent regulations. Rolf Lunder hindered the spread of this idea, by pointing out that it would be hard to find another country that had stricter laws than Norway. The regulations covered "all pesticides that are harmful for bees, as long as they are in flower, and this applies to all plants that are in flower - hence also weeds. And more than that can one not really expect from any regulation?" ${ }^{38} \mathrm{He}$ and other actors continued to spread the idea that pesticides were controllable. ${ }^{79}$

Lunder summed up the status of knowledge on the poisoning of bees in 1952: new insecticides were harmful for bees and other pollinating insects. DDT was the least harmful, and could be used in the evening and at night during flowering. Hexa-pesticides were considerably more harmful and worst of all were phosphate-based agents (in Norway: Bladan and Parathion).

\footnotetext{
71 “Bipestnemdas årsmelding for 1946," Birøkteren (March 1947), 53-55.

72 Rolf Lunder, “Kontrollstasjonene i mai," Birøkteren (May 1947), 120.

73 “Frukttresprøyting og bier," Birøkteren (December 1949), 185-86, on 185.

${ }^{74}$ Ibid.

75 Ibid., on 186.

76 "Minneliste for hagedyrkere 1948," Birøkteren (April 1948), 57. The number of articles in The Beekeeper mentioning pesticides in 1933-1934: 12, 1935-1936: 9, 1937-1938: 9, 1939-1940: 9, 19411942: 2, 1943-1944: 0, 1945-1946: 2, 1947-1948: 7, 1949-1950: 11, 1951-1952: 21.

77 “Birøkt og fruktdyrking," Birøkteren (April 1951), 49-50. Expert of knowledge e.g.: H.M. Røkholt, "Bier - blomster - kjemikalier," Birøkteren (March 1952), 31-34.

${ }^{78}$ Rolf Lunder, "Bier og sprøytemidler," Birøkteren (Januar 1950), 12.

79 E. Haakonsrud, "Frukttresprøyting og bier," Birøkteren (March 1952), 35; Olav Brendlien, "Frukttresprøyting og bier," Birøkteren (July 1952), 118. Sven Edin, "Birøkt og frukdyrking," Birøkteren (June 1951), 102.
} 
These strong nerve-agents were active for several days, the bees took the poison with them back to the hive, where they "begin to fight with each other, behave completely abnormally and the colony can be completely destroyed." ${ }^{80}$ Where it concerned hormone-agents, the beekeepers were of the opinion that they were poisonous, but the researchers did not agree. Nevertheless, Lunder advised against spraying with these herbicides during flowering. ${ }^{81}$ From 1 January 1953 hormone preparations were also marked as harmful for bees, and came under the same regulation as other pesticides. ${ }^{82}$

\section{Conclusion: actors, positions and knowledge}

Suryanarayanan and Kleinman investigated how lay experts, beekeepers, took part in a conflict that affected their lives and work in the United States in the 2000s, and the interaction between knowledge and ignorance. ${ }^{83}$ The American beekeepers were unified in their aim to provide good pollination in agriculture, but were nevertheless divided on the connection between CCD and pesticides. The beekeepers in Norway in the 1930s had a shared aim of getting the most possible honey from the hive, but were divided as to whether pesticides posed a problem to production. Those beekeepers who also produced fruit searched for a practice that made it possible to combine the two businesses. They did not consider stopping the use of pesticides because those pesticides took care of another problem: insects that damaged their fruit production. For beekeepers who were just involved in the production of honey, pesticides created problems. These beekeepers tried to circulate knowledge that showed that pesticides were harmful, also for fruit production, because they killed the honeybees and other pollinators. Their knowledge was hindered from being spread.

The lay experts expressed their conclusions quantitatively and qualitatively, but in parameters that were not exact. ${ }^{84}$ This knowledge was not useful and was not meaningful to researchers in the field at the beginning of the 2000s, as it had been ignored by the "experts of knowledge" in Norway in the 1930s. Applied entomology came in to being as a science at the beginning of the 1900s and created a scientific regime where experts gathered knowledge about honeybees by isolating individual factors that could lead to acute deaths. This knowledge, which oversaw

\footnotetext{
80 Rolf Lunder, "Fra den 14de internasjonale birøkterkongress i England. Foredrag ved Norges Birøkterlags møte under Landbruksveka 1952," Birøkteren (July 1952), 112-14, on 114.

${ }^{81}$ Ibid., 112-14.

${ }^{82}$ Helge Rosenberg, “Årsmøet i Norges Birøkterlag med Oslolaget som framifrå vertskap,” Birøkteren (September 1952), 141-45.

83 Suryanarayanan and Kleinman, "Be(e)coming experts," 216. About lay experts or actors without scientific knowledge but experts on their field, like the beekeepers, and their interaction with science see e.g. Jeremy Vetterm, ed., "Lay Participation in the History of Scientific Observation," Special issue, Science in Context 24, no. 2 (2011).

${ }^{84}$ Suryanarayanan and Kleinman, "Be(e)coming experts," 223.
} 
the chronic effects and interactions between several factors, was published in specialist peerreviewed articles, in popular science publications, and was disseminated at conferences and to beekeepers. This was knowledge that was balanced between the needs of the organisation paying for the study, a need for peer-review, and a desire to provide beekeepers with information that could strengthen their political agenda - to keep beekeeping alive as a profession. ${ }^{85}$

This study illustrates that the experts already had the same considerations in Norway in the 1930s. Rolf Lunder stood between the beekeepers and their practical knowledge on the one side, and the state that financed his position and the research he was undertaking on the other. And lastly, he stood as a researcher in a scientific tradition, with its requirements for hypothesis, theory and method. Lunder was familiar with beekeeping and understood the connection between the bees, the pesticides and the agricultural landscape, but he was open to the idea that the bees crawling around on the ground and then dying could be caused by a sickness. Lunder emphasised that fruit production was dependant on the use of pesticides and the research he carried out was probably designed with this presumption. ${ }^{86} \mathrm{He}$ produced knowledge on how the bees and the pesticides could function side by side, and he did not consider that the observations of the beekeepers presented an alternative set of information. For him the knowledge was only trustworthy as long as the research was designed and implemented according to methods he could control and that he trusted. In this way Lunder also produced and shared ignorance of the complex connection between honeybees and pesticides and what made it a difficult system to control. The system that made this production of knowledge and ignorance possibly came about according to Suryanarayanan and Kleinman, in the United States at the beginning of the 1900s, and was present in Norway in the 1930s.

This system gave actors outside of the Norwegian beekeeping community epistemic power, and they used this power to influence the regulations. These actors were primarily the State Entomologist and beside him the State Horticulturalist. Their job and knowledge were directed towards finding, identifying and eradicating damaging insects. The bees and their needs were secondary; regulation of the use of pesticides needed to be designed to allow the fruit growers to protect their fruit against pests.

The Bee Sickness Committee looked for sickness in the hives, but at that time pesticide poisoning was not considered to be a sickness, but was understood as the results of accident or incompetent use of the chemicals. The majority of the members of the committee were experts within limited specialisms, who came with their own knowledge and requirements. Many of them were members of an international network of peers, where pesticides were

\footnotetext{
85 Ibid., 227.

${ }^{86}$ About false positive orientation and false negative orientation in research design see Suryanarayanan and Kleinman, Vanishing Bees Science, 99.
} 
an unquestionable part of a scientific tradition and a "rational" agriculture. Most of the beekeepers who wrote in The Beekeeper kept bees as a hobby and wanted to get the bees and the pesticides to work together. The negative effects of lead arsenate on human health were already well known in the 1930s, but none of the actors in The Beekeeper put forward such knowledge. If they had, it would have questioned the idea that poisons in general (including pesticides) could function as remedies that targeted one species at a time.

The beekeepers who had their hives poisoned in spring 1935 did what they were told to: they collected samples of bees, sent them to Lunder and they did a survey. The result was evident, but still neither the beekeepers nor the Norwegian Beekeepers Society relied on them. The knowledge generated by the beekeepers, who were experts by their practice (lay experts), was sent to experts with academic knowledge with a request to establish a final answer to the question of whether pesticides were dangerous to bees. By doing so the beekeepers legitimated the superiority of these experts' knowledge. On the other hand, beekeepers knew they had the best knowledge of bees, but not of pesticides. They asked the experts on pesticides for a solution: these experts worked within the Norwegian agricultural system, to which the beekeepers also belonged. Beekeepers got both financial and technical support from this system, as did other farmers. The Norwegian government during the 1930s regarded beekeeping as an opportunity for minor farmers to expand their income, and as the counties had their horticulturalist, they had a specialist on beekeeping. Actors in this agricultural system wanted to improve Norwegian agriculture, and pesticides were a tool to do so, as both beekeepers and other actors in this system confirmed. These actors shared values, and this may explain why beekeepers who tried to circulate knowledge about pesticides as harmful to bees and beekeeping in general were hindered; their knowledge did not fit into the image of a modern agriculture.

The poisoning of bees bore witness to the fact that a modern, effective and industrial agriculture had a negative side. There was a similar conflict of interests in industry where socio-economic advantages that came from the establishment of new industries, had a negative side, in terms of damage to the health of workers and to the environment. In the nineteenth century those in power sought help from science to handle such conflicts of interest. Science led to the development of technology that could identify chemicals and enable increasingly more precise measurement of the amount of poisonous substances. In addition, scientists would design models that made it possible to decide how much of a certain poisonous substance nature could withstand, which thereby made it possible to regulate the use of certain substances. This gave scientific knowledge and scientific expertise a central role in the regulation of poisonous substances. Science also became the guarantee that the system of regulation functioned as it 
should. ${ }^{87}$ This same trust and power was also given to the Norwegian scientific expertise and the others who affected the circulation of the idea that pesticides were necessary and possible to control. These actors had as a prerequisite, the perception that the pesticides could be used in such a way that the bees survived, whilst the targeted insects would be poisoned. This may be another reason why the knowledge of the beekeepers, who questioned the properties of the pesticides, were ignored or stopped, and were not taken into consideration when writing the regulation in 1941.

Increased use of pesticides and larger areas of mono-culture gradually made the situation worse for both bees and beekeepers. In the decade following 1953 the Norwegian beekeepers continued to complain of the fatal consequences of the pesticides, but the circulation of the understanding that pesticides were necessary, most likely strengthened the impression that the bees, the beekeepers and their production, had to adjust to the pesticides. In Norway a general agreement around the issue was created with the regulations in 1941. This agreement was established by the actors who had epistemic dominance and power, and was supported by both beekeepers and others. The agreement closed the issue. In the years following, new pesticides were detected as harmful to bees, and came under this regime that regulated when and where to use them. The perception of toxicity did not change, that it occurs at the interface between poison and the targeted species. The power in the discourse of toxicity was held by the actors with this understanding. Even today, this is the way pesticides are perceived; as remedies that are controllable when it comes to the effect on the environment.

${ }^{87}$ Soroya Boudia and Nathalie Jas, eds., Powerless Science? Science and Politics in a Toxic World (New York - Oxford: Berghahn Books, 2014), 1-2, 5; In Norway: Kristin Asdal, "Politikkens teknologier: produksjoner av regjerlig natur" (PhD diss., University of Oslo, 2004). 